\title{
Lepidoptera recorded on snow in Central Poland
}

\author{
Agnieszka Soszyńska-Maj \& Jarosław Buszko
}

Soszyńska-Maj, A. \& Buszko, J. 2011: Lepidoptera recorded on snow in Central Poland. - Entomol. Fennica 22: 21-28.

Sixteen species of Lepidoptera, belonging to 10 families, were recorded on snow in Central Poland. Two episodes of mass occurrence on snow were observed: adults of Operophtera brumata and larvae of Euthrix potatoria. Twelve species were recorded from snow for the first time in general. Three ecological groups of snow active Lepidoptera were distinguished: 1) autumn and winter active moths, 2) overwintering species which could be periodically activated from diapause, and 3) early spring active species. The ecology of winter active Lepidoptera is discussed. All were classified as chionoxenes, while $O$. brumata was considered as the moth most regularly recorded on snow and most likely to be met in winter.

A. Soszyńska-Maj, Department of Invertebrate Zoology \& Hydrobiology, University of Łódź, Banacha 12/16, 90-237 Łódź, Poland; E-mail: agasosz@biol.uni.lodz.pl

J. Buszko, Department of Animal Ecology, Nicolaus Copernicus University, Gagarina 9,87-100 Toruń,Poland; E-mail: buszko@biol.uni.torun.pl

Received 5 May 2010, Accepted 27 October 2010

\section{Introduction}

In areas with a snow cover during winter, certain cold tolerant poikilothermic organisms are more or less winter active. This is an evolutionary and ecologically explicable behaviour. Even at very low air temperature in winter, the temperature of soil and litter below snow (the so-called subnivean space) can remain close to $0^{\circ} \mathrm{C}$. Due to its high air content, snow has a high insulation capacity and low thermal conductivity. Snow with low density and a certain thickness provides the greatest insulation and enables subnivean activity of invertebrates throughout the winter (Aitchison 1974, 2001). Certain ectothermic organisms, such as Boreus sp., Chionea sp. or some springtails and spiders, use the favourable weather conditions on mild winter days with low air pressure, when the temperature is stable, for migration, predation and even copulation (Aitchison 2001,
Hågvar \& Greve 2004, Soszyńska 2004, Soszyńska-Maj, unpubl.), and stay inactive when the weather is disadvantageous.

The invertebrate fauna active on the snow surface (supranivean fauna) consists of regular, however weather depending, snow active species and includes the following ecological groups: chionobionts, specialized in snow activity and winter reproduction, stenothermic; chionophiles, regularly snow active but occur also in other seasons, eurythermic; chionoxenes, occur on snow only accidentally but adapted to low temperature (Pruitt 1978).

The invertebrate fauna present on snow is strongly weather dependent. Very few papers have been published as a result of regular investigations, not only accidental trips. Well known for their snow surface activity are springtails (Collembola), scorpionflies (Mecoptera), flies (Diptera) from the families Trichoceridae, Myceto- 
philidae, Limoniidae, Chironomidae and Phoridae; beetles (Coleoptera) especially from the families Cantharidae, Carabidae and Staphylinidae; as well as stoneflies (Plecoptera), caddishflies (Trichoptera) and bugs (Heteroptera) (Tahvonen 1942, Szulczewski 1947, Ackefors 1964, Aitchison 2001, Soszyńska \& Durska 2002, Hågvar \& Greve 2004, Soszyńska 2004, Hågvar 2010). The snow activity of spiders is also well known (Aitchison 2001, Hågvar \& Aakra 2006).

Activity of Lepidoptera on snow has not earlier been studied consistently. However, the winter activity of Geometridae and the problem of winglessness of winter moths (Roff 1990, Sattler 1991, Peterson \& Nilssen 1998, Tammaru et al. 2001), as well as the influence of weather factors on the activity of Noctuidae is well studied (Buszko \& Nowacki 1991). In Poland, the winter activity of Lepidoptera was studied by Adamczewski $(1936,1964)$ and by Buszko and Nowacki $(1990,1991)$. The data only about Lepidoptera on snow in Poland were presented by Szulczewski (1947) and Soszyńska-Maj (2008).

The aim of this paper is to present Lepidoptera recorded on the snow surface during regular investigations in Central Poland, to describe the weather conditions under which they were active, and to discuss their winter strategy.

\section{Study area}

The study area is located in Central Poland, in the vicinity of Łódź, one of the biggest cities in Poland. According to the principles established by Kondracki (2000), which correlate with physicogeographical division of Europe, the area is called the Lodz Upland. It is the northernmost upland area in Poland, with maximum of $284 \mathrm{~m}$ above sea level, surrounded with lowlands and characterized by postglacial landforms, lowest temperature, highest air humidity and longest snow-covered period in Central Poland. Partly it is protected within Lodz Uplands Landscape Park (Kurowski 1998).

The snow cover appears regularly in Central Poland, but its onset and duration vary among years. In winter seasons 1998-2002, the first snow falls was noticed between the mid-November and the end ofDecember, and snow cover laid from 30 to 65 days of the year (unpublished data from Lodz Meteorological Station).

Lepidoptera were sampled in nature reserves and within the largest forest areas. Investigations were made particularly in the dominating forest associations: mixed forests containing old beeches, spruces and firs, riparian forests ( $\mathrm{Cir}$ ceo-Alnetum) in vicinity of springs, acidophilous beech woods (Luzulo pilosae-Fagetum) containing 100-years old beeches and dry-ground forests (Tilio-Carpinetum).

\section{Material and methods}

This research is a part of more general investigation of the snow-surface active fauna of Central Poland during four autumn-spring periods from 1998 to 2002. Few data came from other winters. Semi-quantitative samplings were made, if at all possible, every day during winter with snow cover, from November to March, in the temperatures ranging from -10 to $+10^{\circ} \mathrm{C}$ in comparable daily periods of time $(1.5 \mathrm{~h})$. Colder and warmer days were skipped. On account of weather-depending activity of this fauna, short day in winter and lower temperature in the morning, the sampling was made between $9.30 \mathrm{a} . \mathrm{m}$. and 3.00 p.m.

The association of the occurrence of snow-active invertebrates with weather conditions was investigated, noting air temperature, humidity and the depth of the snow cover each time. The air temperature and humidity were measured $1 \mathrm{~m}$ above the snow surface in the shade.

The seasons were defined according to Klysik (2001) for Central Poland. Autumn was defined as October, early winter as November until midDecember, winter as the period between mid-December and March, early spring as March, and spring as April.

\section{Results}

Sixteen species of Lepidoptera, belonging to 10 families were identified on snow, most for the first time. Altogether 139 adults and 2 larvae of Lepidoptera were collected and numerous larvae of Euthrix potatoria were observed on snow. One species, Caryocolum junctella, was found in Central Poland for the first time. The others are 
Table 1. No. of collected specimens of Lepidoptera on snow in Central Poland with dates, air temperatures and sampling sites.

$\begin{array}{llll}\text { Family } & \text { No. Date } & \mathrm{T}\left({ }^{\circ} \mathrm{C}\right) \text { Site } \\ \text { Species } & \text { No. }\end{array}$

Gracillariidae

Phyllonorycter agilella (Zeller, 1846)

19 28 XII $1999 \quad 0 \quad$ Wolbórka res.

Ypsolophidae

Ypsolopha ustella (Clerck, 1759)

$\begin{array}{llll}19 & 7 \text { II } 1999 & -2 & \text { Las Łagiewnicki } \\ 19 & 8 \text { III } 2004 & +2 & \text { Molenda res. }\end{array}$

Lyonetiidae

Lyonetia clerkella (Linnaeus, 1758)

$19 \quad 24 \times 11999+2 \quad$ Las Łagiewnicki

$1 \delta 25$ XI $1999+1$ Wiączyń res.

\section{Gelechiidae}

Caryocolum junctella (Douglas, 1851)

res.

$19 \quad 1 / 2001 \quad-2.5$ Parowy Janinowskie

\section{Tortricidae}

Tortricodes alternella (Denis et Schiffermller, 1775)

$\begin{array}{rrrl}19 & 28 \text { III } 1995 & 0 & \text { Las } \text { Łagiewnicki } \\ 19 & 30 \text { III 2001 } & +1 & \text { Molenda res. }\end{array}$

Pieridae

Gonepteryx rhamni (Linnaeus, 1758)

$19 \quad 19$ IX $1997 \quad-2 \quad$ Las Łagiewnicki

Lasiocampidae

Euthrix potatoria (Linnaeus, 1758)

$\begin{array}{llrl}1 & 19 \mid 2006 & - & \text { Szczekociny } \\ 2^{2} & 8 \text { III } 2006 & -4 & \text { Spała }\end{array}$

Geometridae

Archiearis parthenias (Linnaeus, 1761)

Agriopis leucophaearia (Denis et Schiffermüller, 1775)

Colotois pennaria (Linnaeus, 1761)

Alsophila aceraria (Denis et Schiffermller, 1775)

Operophtera brumata (Linnaeus, 1758)

Operophtera fagata (Scharfenberg, 1805)

$19 \quad 28$ III $2001 \quad-1 \quad$ Gałków res

1 으 30 III $2001+6 \quad$ Struga Dobieszk. res.

$1928 \times 1997 \quad 0 \quad$ Las Łagiewnicki

$1928 \times 1997-2 \quad$ Las Łagiewnicki

$28 \quad 23$ XI $1999-1 \quad$ Grądy n. Lindą res.

$7579^{3} 19 \times 11999 \quad 0$ Molenda res.

15 인 21 XI $1999 \quad-1 \quad$ Gałkówek res.

8 - 23 XI $1999 \quad-2$ Dąbrowa Grotnicka res.

6823 XI $1999-1 \quad$ Grądy nad Lindą res.

19 24 XI $1999+1 \quad$ Las Łagiewnicki

2 29 27 XII $1999+1$ Park Zdrowie - Łódź

$10 \quad 12$ XII $2001 \quad 0 \quad$ Kruszewiec res.

1 2 21 XII $2002 \quad-3 \quad$ Wiączyń res.

1 20 XI $1997-1 \quad$ Las Łagiewnicki

1 1이 $\quad 271993 \quad-6 \quad$ Las Łagiewnicki

Noctuidae

Conistra rubiginosa (Scopoli, 1763) $\quad 19 \quad 6$ III 1995 +2 Las Łagiewnicki

Conistra vaccinii (Linnaeus, 1761)

1920 XI $1997-1 \quad$ Las Łagiewnicki

Nolidae

Nycteola revayana (Scopoli, 1772)

$\begin{array}{rlrl}10 & 26 \text { II } 1999 & +2 & \text { Las Łagiewnicki } \\ 1 \delta & 25 \text { XI } 1999 & +1 & \text { rez. Wiączyń } \\ 1 \delta & 3 \text { I } 2001 & 0 & \text { Rogów - Arboretum } \\ 10 & 31 \text { I } 2004 & -1 & \text { Las Łagiewnicki }\end{array}$

1 Numerous larvae were observed, J. Tabor \& L. Maksalon pers. comm.

2 Larvae.

3 Many more females were observed, but not collected. 
a
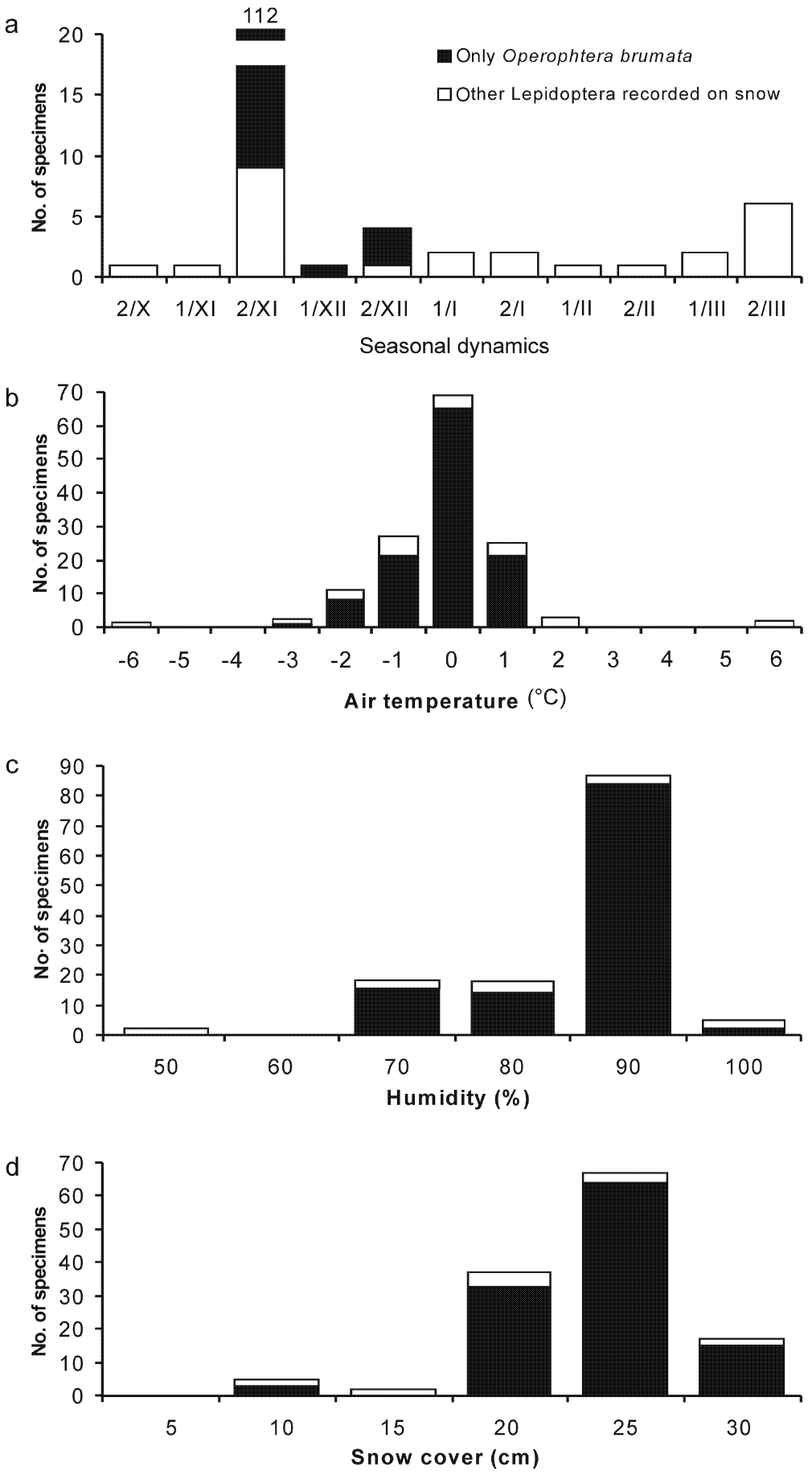

Fig. 1. Lepidoptera on snow in Central Poland in four winter seasons 1998-2002. - a. Seasonal dynamics. First and last halves of months in Arabic numerals preceding months in Roman numerals. $-b-d$. No. of Lepidoptera in relation to environmental variables.

widely distributed in Poland (Buszko \& Nowacki 2000).

Detailed data of sampling site, date, temperature and number of collected specimens are presented in Table 1. Lepidoptera had only $2.2 \%$ share in collected material $(6,325$ specimens of all invertebrates collected from snow). They were one of the least numerous orders of snow active insects, but with almost $20 \%$ constancy in the whole material. 
Most of the collected lepidopteran species, as well as of the specimens belonged to the family Geometridae. One species, Operophtera brumata, clearly predominated in the collected material $(83.6 \%)$. Wingless females of this species were found on snow more often than winged males.

Two episodes of mass occurrence of moths on snow were observed. In November 1999, more than hundred individuals of wingless females of O. brumata were found walking on snow at $0^{\circ} \mathrm{C}$, while the males were sitting on trunks of nearby trees (the same was observed in other days). Hundreds of caterpillars of Euthrix potatoria were seen in January 2006 walking on snow (J. Tabor and L. Maksalon pers. com.).

The largest catches of Lepidoptera took place in early winter and early spring. However, the early autumn peak was made by the great number of the dominant species, O. brumata. Lepidoptera were found throughout the whole winter period from November to March (Fig. 1a). Lepidoptera occurred on snow from -6 to $+6^{\circ} \mathrm{C}$, with the peak at -1 and $+1^{\circ} \mathrm{C}$ (Fig. 1b). All catches were made on overcast weather. They preferred air humidity above $70 \%$ (with peak on $90 \%$ ) (Fig.1c), and the snow cover was usually at least $20 \mathrm{~cm}$ deep (Fig. 1d).

\section{Discussion}

Before this study, five species of Lepidoptera have been recorded on snow in Poland: three geometrids, Operophtera fagata (in December at $-1^{\circ} \mathrm{C}$ ), Apocheima pilosaria (in March at $+2^{\circ} \mathrm{C}$ ) (Szulczewski 1947) and O. brumata, as well as Ypsolopha ustella (Ypsolophidae) and Tortricodes alternella (Tortricidae) (Soszyńska-Maj 2008). Four others have been recorded in Finland in January: Acleris hastiana (Tortricidae), Caloptilia elongella (Gracillariidae) (Levander 1913), Epiplema crenana (Geometridae) at $3,5^{\circ} \mathrm{C}$ and larvae of a noctuid moth Agrotis sp. (Tahvonen 1942). In our study, Lepidoptera were active on snow when temperature ranged from -6 to $+6^{\circ} \mathrm{C}$ (Fig. 1b). The highest number of specimens was observed at $0^{\circ} \mathrm{C}, 90 \%$ of air humidity and snow depth over $15 \mathrm{~cm}$ (Fig 1b-d.).

Continental winter is so severe that it divides the cold season invertebrates into late and early emerging species. Autumn, winter and early spring active species differ in their ecological reaction to winter conditions and snow, which is expressed in different behavior as well as in morphological and physiological adaptations. Lepidoptera collected on snow in Central Poland were classified into three ecological groups considering the time of emergence, short or long life, and hibernation: 1 . autumn and winter active moths, 2. overwintering species which could be periodically activated from diapause, and 3. early spring active species. The characteristics of these groups is presented below.

One species collected on snow in Central Poland belongs to the group of autumn active moths. Colotois pennaria (Geometridae) has one generation, flies in the autumn until the first frost, usually from September to early December and overwinters as an egg (Waring \& Townsend 2006). To winter moths belong: Alsophila aceraria, Operophtera brumata and O. fagata (Geometridae). These species overwinter as eggs and their larvae appear in April and are thus springfeeding. $O$. brumata has one generation and flies from October to January, while $O$. fagata mainly in November (Waring \& Townsend 2006). This behavior is connected with larval polyphagy, female winglessness, short-lived adults which do not survive winter, do not feed and their mouth parts are usually reduced (Sattler 1991, Tammaru et al. 2001). Males of $O$. brumata are capable of flying even in $-2.6^{\circ} \mathrm{C}$ (Buszko \& Nowacki 1991) but their flight is slow and poorly controlled. Females emerge from pupae in early winter with fully developed eggs and mate with males on tree trunks. Protandry is characteristic for O. bruma$t a$, males emerging one week ahead of females to maximize mate availability (Peterson \& Nilssen 1998). Newly hatched larvae are ready to exploit fresh foliage in the spring. Females of the winter active moths make up the largest category among Lepidoptera with reduced wings. Fligthlessness is possible in stable habitats that provide steady resources (e.g. forest), with dispersal in the larval stage. It brings advantages such as increasing crypsis and reducing body size to minimize heat loss (Sattler 1991). Sattler (1991) as well as Peterson and Nilssen (1998) suggested that cold season Geometridae emerge and mate in early winter because of reduced predation pressure. 
Predatory beetles from families Staphylinidae and Carabidae, and red wood ants in particular (Tammaru at al. 2001) are dormant, insectivorous mammals hibernate, migratory birds are absent and resident populations of birds change their diet from insects to seeds (Peterson \& Nilssen 1998). However, insectivorous mammals from family Soricidae as well as beetles from families Staphylinidae and Carabidae are winter active and create subnivean winter food chains (Aitchison 1984). Peterson and Nilssen (1998) concluded that $O$. brumata emerges in a narrow time period just before winter, as a result of two opposing selective forces - migrating of insectivorous birds and first snowfalls. Birds can easily prey on the wingless females and snow cover prevents emergence (Peterson \& Nilssen 1998). However, the first snow in Central Poland used to fall at the end of November during the observed peak of activity of $O$. brumata. Other studies are needed to find the precise time of emerging of $O$. brumata in Central Poland. Waring \& Townsend (2006) pointed that both sexes of $O$. brumata can be found resting or walking up tree trunks after dark. In November 1999 in "Molenda" reserve more than hundred wingless females were observed walking on snow at $0^{\circ} \mathrm{C}$ at noon while males were seen resting on tree trunks. Hannig et al. (2006) observed this species on tree trunks in Germany in November and December.

The second group of snow-active Lepidoptera comprises species overwintering the cold season in the adult stage. In contrast to the previous group, they have long adult phase, both sexes have normally developed wings and mouth parts: Ypsolopha ustella (Ypsolophidae), Caryocolum junctella (Gelechiidae), Conistra rubiginosa, C. vaccinii (Noctuidae), Gonepteryx rhamni (Pieridae), Lyonetia clerkella (Lyonetiidae) and Nycteola revayana (Nolidae).

In general, a minority of Lepidoptera passes the cold season as adults and only some of them may be active in winter. Buszko and Nowacki (1991) reported that in Poland about 100 species overwinter as adults, among them 20 belong to Noctuidae. The above mentioned authors recorded 12 species of Noctuidae to be active in winter in central Poland, with three species observed during the whole cold period: Eupsilia transversa (never seen on the snow), Conistra vaccinii and $C$. rubiginosa. These three moths have also been observed during winter on tree trunks in Germany (Hannig et al. 2006). On British Isles, C. vaccinii is one of the commonest winter species, it flies from September to May and can be found visiting flowers (Kimber 2010). Noctuidae stay in diapause in various hidden places: in litter, under bark of trees or in hollows of trees during periods of unfavorable weather. However, Noctuidae can break the diapause when the air temperature is increasing (Buszko \& Nowacki 1991). They are not adapted to stay active in such low temperatures like Geometridae. Both sexes feed, have fully developed mouth, and live up to nine months in adult stage. Thanks to well developed wings, Noctuidae are capable to fly in low temperatures at $+0,5^{\circ} \mathrm{C}$ to search for food, hiding place and oviposition sites (Adamczewski 1950, Sattler 1991). Their longevity requires supplementary feeding in low temperatures, so there is no example of flightlessness in this group of species (Sattler 1991). Long period of frost induces an obligatory diapause, which must come to the end without a break. C. rubiginosa is well adapted to low temperature and is not used to overwinter in diapause. It is most active in December and January (Adamczewski 1950, Buszko \& Nowacki 1991).

L. clerkella has two or more generations and flies all year round in Europe, and $N$. revayana occurs from September to July. Both overwinter as adults and reappear in the spring. Y. ustella overwinters as an adult and can be found on wing during this period (Kimber 2010). This moth drinks water from the wet snow, which was observed in laboratory after collection on snow (Fig. 2.). Similarly to other moths recorded on snow it did not fly but walked on snow surface. It is known from literature that many species from Gracillaridae, Gelechidae and Tortricidae also belong to this group, as well as from several other families of Lepidoptera with species overwintering as adults (Sattler 1991).

The last group consists of short-lived species which overwinter as pupae and adults appear in early spring: Agriopis leucophaearia, Archiearis parthenias, Tortricodes alternella. Females of $A$. leucophaearia are wingless and mate with males on tree trunks, and adults are active from early February to mid March (Kimber 2010). This spe- 


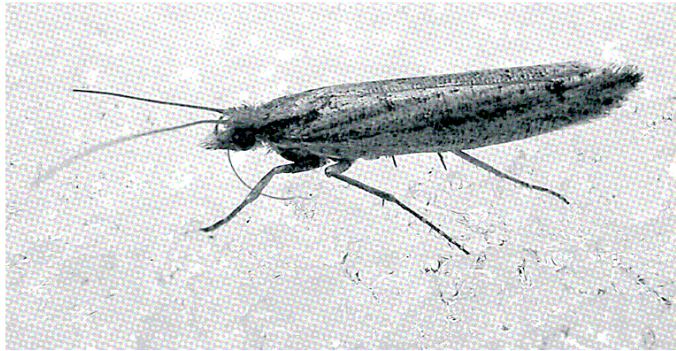

Fig. 2. Ypsolopha ustella drinking water from snow in laboratory (photo by M. Grabowski).

cies was found on tree trunks in Germany in January and February (Hannig et al. 2006). A. parthenias has one generation flying from March to April (Waring \& Townsend 2006) while $T$. alternella is one of the earliest flying tortricids (Kimber 2010).

Euthrix potatoria does not belong to any group mentioned above. This species overwinters as small larva and its caterpillars were observed moving on the snow surface in January and March. The name of E. potatoria comes from the habits of larvae, which are known from drinking water from drops of dew and rain. Probably the humidity of snow surface creates favorable conditions for their activity.

Analysis of all available data allowed us to classify the Lepidoptera recorded on snow as chionoxenes - accidentally visiting snow surface. However, one species, O. brumata, may be considered as the most regularly snow active species among all Lepidoptera. Its appearance on the snow is often reported to be related to the late autumn biology of the species, but normally $O$. brumata hatches and reproduces before snow fall. Recent papers indicate that winter-active omnivorous small mammals (Soricidae) feed on subnivean winter-active invertebrates (Ackefors 1964, Aitchison 1984, Itämies \& Lindgren 1989). Wingless females of Geometridae, frequently recorded on snow surface in early winter, can be an important element of the winter diet of shrews, as suggested by that we found shrews trapped in Mochrick traps placed above the snow surface (unpublished data).

Acknowledgements. We would like to thank Ludwik Maksalon and Jacek Tabor for information about Euthrix potatoria, and Michał Grabowski and Karolina Bącela for correcting the English version of the manuscript. We are grateful to Sigmund Hăgvar and an anonymous referee for their comments on the manuscript.

\section{References}

Ackefors, H. 1964: Winteractive shrews in the subnivean environment. - Zoologisk Revy 26: 16-22.

Adamczewski, S. 1936: Pojawy motyli w okolicach Warszawy w roku 1934. — Fragmenta Faunistica 2: 305313. [In Polish.]

Adamczewski, S. 1950: Reagowanie owadów na promienie pozafiołkowe. - Fragmenta Faunistica 6: 95-110. [In Polish.]

Adamczewski, S. 1964: Materiały do poznania wędrówek motyli w Polsce. II. Jesienne pojawy i migracje motyli w Warszawie i Białowieży w latach 1961 i 1962 . Fragmenta Faunistica 11:319-374. [In Polish.]

Aitchison, C. W. 1974: A sampling technique for active subnivean invertebrates in southern Manitoba. - The Manitoba Entomologist 8: 32-36.

Aitchison, C. W. 1984: A possible subnivean food chain. - In: Merritt, J. F. (ed.), Winter Ecology of Small Mammals: 362-372. Carnegie Museum of Natural History, Pittsburgh. 392 pp.

Aitchison, C. W. 2001: The effect of snow cover on small animals. - In: Jones, H. G., Pomeroy, J., Walker, D. A. \& Hoham, R. (eds.), Snow ecology: 229-265. Cambridge University Press. 378 pp.

Buszko, J. \& Nowacki, J. 1990: Łowność sówkowatych na światło i przynętę pokarmową. - Wiadomości Entomologiczne 9: 13-20. [In Polish.]

Buszko, J. \& Nowacki, J. 1991: Aktywność zimowa sówkowatych (Lepidoptera, Noctuidae). - Wiadomości Entomologiczne 10: 35-42. [In Polish.]

Buszko, J. \& Nowacki, J. (eds.) 2000: The Lepidoptera of Poland. A distributional Checklist. Polish Entomological Monographs. 1. - PTE, Poznań, Toruń. 178 pp.

Hannig, K., Reissmann, K. \& Schwerk, A. 2006: Zur Verbreitung, Phenologie und Temperaturpräferenz von Calodromius bifasciatus (Dejean, 1825) in Nordrhein-Westfalen (Coleoptera: Carabidae). - Entomologische Zeitschrift 116: 171-178.

Hågvar, S. \& Greve, L. 2004: Winter active flies (Diptera, Brachycera) recorded on snow - a long-term study in south Norway. - Studia Dipterologica 10: 401-421.

Hăgvar, S. \& Aakra, K. 2006: Spiders active on snow in Southern Norway. - Norwegian Journal of Entomology 53: 71-82.

Hågvar, S. 2010: A review of Fennoscandian arthropods living on and in snow. - European Journal of Entomology 107: 281-298.

Itämies, J. \& Lindgren, E. 1989: What food is there available for shrews during the winter - Aquilo, Serie Zoologica 24: 33-49.

Kimber, I. 2010: Online guide to the moths of Great Britain and Ireland. - [www document]. URL http:/lukmoths.org.uk/. (Site visited on 6 April, 2010) 
Kłysik, K. 2001: Warunki klimatyczne. - In: Liszewski, S. (ed.), Zarys monografii województwa łódzkiego: 68-81. Łódzkie Towarzystwo Naukowe, Łódź. 456pp. [In Polish.]

Kondracki, J. 2000: Geografia regionalna Polski. - PWN, Warszawa. 442 pp. [In Polish.]

Kurowski, J. K.(ed.) 1998: Park Krajobrazowy Wzniesień Łódzkich. — Eko-Wynik, Łódź. 183 pp. [In Polish.]

Levander, K. M. 1913: Ett bidrag till knnedom om vår vinterfauna. - Memoranda Societatis pro Fauna et Flora Fennica 39: 95-104. [In Swedish.]

Peterson, N. A. \& Nilssen, A. 1998: Late autumn eclosion in the winter moth Operoptera brumata: compromise of selective forces in life-cycle timing. - Ecological Entomology 23: 417-426.

Pruit, W. O. Jr 1978: Boreal ecology. — Edward Arnold, London. 73 pp.

Roff, D. A. 1990: The evolution of flightlessness in insects. - Ecological Monographs 60: 389 421.

Sattler, K. 1991: A review of wing reduction in Lepidoptera. - Bulletin of British Museum for Natural History (Entomology) 60: 243-288.

Soszyńska, A. \& Durska, E. 2002: Cold-adapted scuttleflies species of Triphleba Rondani (Diptera: Phoridae). - Annales Zoologici 52: 279-283.
Soszyńska, A. 2004: The influence of environmental factors on the supranivean activity of Diptera in Central Poland. - European Journal of Entomology 101: 481-489.

Soszyńska-Maj, A. 2008: Znaczenie kompleksów leśnych dla zachowania różnorodności gatunkowej fauny naśnieżnej miasta Łodzi. — In: Indykiewicz, P., Jerzyk, L. \& Barczak, T. (eds.), Fauna miast. Ochronić różnorodność biotyczną w miastach: 78-82. SAR Pomorze", Bydgoszcz. 634 pp. [In Polish.]

Szulczewski, J. 1947: Fauna naśnieżna Wielkopolskiego Parku Narodowego. - Prace Monograficzne nad Przyrodą Wielkopolskiego Parku Narodowego pod Poznaniem 2: 1-17. [In Polish.]

Tahvonen, E. 1942: Beobachtungen über Winterinsekten. - Suomen Hyönteistieteellinen Aikakauskirja 8: 203-214.

Tammaru, T., Tanhuanpää, M., Ruohomäki, K. \& Vanatoa, A. 2001: Autumnal moth - why autumnal? Ecological Entomology 26: 646-654.

Waring, P.\& Townsend, M. 2006: Field guide to the moths of Great Britain and Ireland. - British Wildlife Publishing, 432 pp. 